\title{
PENERAPAN MODEL COOPERATIVE SCRIPT UNTUK MENINGKATKAN KETERAMPILAN SISWA MEMBACA TEKS EKSPOSISI
}

\author{
Mardewi \\ Program Studi Pendidikan Bahasa dan Sastra Indonesia \\ Universitas Muslim Indonesia, Makassar \\ dewimardewi00@gmail.com
}

\begin{abstract}
Abstrak: Penelitian ini bertujuan meningkatkan kemampuan membaca teks eksposisi siswa kelas X IPS 2 Negeri 18 Makassar. Penelitian ini Menggunakan model Cooperative Script. Jenis Penelitian yang digunakan dalam penelitian ini adalah Penelitian Tindakan Kelas (PTK) yang terdiri dari dua siklus dan setiap siklus dilaksanakan 2 kali pertemuan termasuk tes pada setiap akhir siklus. Prosedur penelitian meliputi perencanaan, pelaksanaan, tindakan, observasi, dan refleksi. Subjek dalam penelitian ini adalah siswa kelas X IPS 2 SMA Negeri 18 Makassar, dengan jumlah 35 siswa. Hasil penelitian pada prasiklus berada pada kategori rendah dengan nilai rata-rata 62 dan secara individual dari 35 siswa hanya 6 siswa (17\%) yang memenuhi Kriteria Ketuntasan Minimal (KKM). Sedangkan pada siklus I berada pada kategori sedang dengan nilai rata-rata 71 dan secara individual dari 35 siswa terdapat 21 siswa (60\%) telah memenuhi KKM. Serta pada siklus II berada pada kategori tinggi dengan nilai rata-rata 82 dan secara individual dari 35 siswa terdapat 31 siswa (89\%) telah memenuhi Kriteria ketuntasan Minimal (KKM). Berdasarkan hasil penelitian, Penerapan Model Cooperative Script Untuk Meningkatan Ketarampilan Membaca Teks Eksposisi siswa X IPS 2 SMA Negeri 18 Komp. Mangga Tiga Permai Daya,Paccerakang, Biring Kanaya, Kota Makassar, Sulawesi Selatan dapat disimpulkan bahwa mengalami proses peningkatan.
\end{abstract}

Kata Kunci: keterampilan membaca, cooperative script, teks eksposisi

\section{PENDAHULUAN}

Bahasa pada hakikatnya memiliki peranan penting dalam kehidupan seseorang. Secara umum, bahasa dapat didefinisikan sebagai alat komunikasi verbal. Istilah verbal dipergunakan untuk membedakan bahasa dari alat-alat komunikasi lainnya, seperti bahasa tubuh, dan bahasa binatang. Istilah verbal juga mengandung pengertian bahwa bahasa yang dipergunakan sebagai alat komunikasi pada dasarnya adalah lambang-lambang bunyi yang bersistem, yang akan dihasilkan oleh artikulator (alat bersuara) manusia, dan sifatnya arbitrary serta konvensional (Tampubolon, 2015: 1).

Sebagai alat komunikasi verbal, inilah fungsi bahasa yang esensial dan umum, serta fungsi ini bersifat sosial. Hal ini dapat dikatakan bahwa bahasa bersifat sosial dikarenakan dalam komunikasi tersebut selalu adanya dua pihak yang terlibat, yaitu pemberi dan penerima informasi. Selain itu, bahasa juga mempunyai arti sebagai alat yang menyatakan dan memahami pikiran dan perasaan, karena dalam menyatakan dan memahami pikiran masing-masing peserta berkomunikasi.

Ada berbagai aspek yang mendasari pentingnya kecakapan berbahasa yang dapat ditinjau pada bidang pendidikan. Peran dari bahasa pun sangat memengaruhi perkembangan intelektual, sosial, dan emosional seorang siswa. Aktivitas bahasa mengenal adanya empat keterampilan berbahasa, yaitu mendengar, berbicara, membaca, dan menulis.

Salah satu keterampilan berbahasa yang penting dipelajari dan dikuasai oleh setiap individu adalah membaca. Membaca adalah suatu proses yang dilakukan serta dipergunakan oleh pembaca untuk memperoleh pesan, yang hendak disampaikan oleh penulis melalui media 
kata-kata/ bahasa tulis (Tarigan, 2018:7). Keterampilan membaca memilki peranan penting dalam setiap pembelajaran. Hal ini dikarenakan membaca dapat menambah ilmu pengetahuan dan memberi pengaruh yang besar dalam menguasai bahasa, baik secara lisan maupun tulisan.

Tujuan pertama pembelajaran membaca secara lebih luas dapat ditafsirkan agar siswa mencintai membaca. Tujuan ini sangat penting sebab mencintai membaca adalah modal awal agar peserta didik bisa membaca sekaligus tetap menjadi pembaca untuk memahami suatu bacaan. Namun demikian, pembelajaran di sekolah rupanya melupakan tujuan ini sehingga sekolah hanya mampu menghasilkan siswa yang dapat membaca tetapi tidak suka membaca dan tidak memperoleh pemahaman isi bacaan. Seorang peserta didik pandai membaca tapi masih menganggap membaca adalah kegiatan yang membosankan. Dalam kaitannya tersebut, seorang pendidik seyogianya membekali siswa dengan starategi pembeajaran yang tepat.

Membaca merupakan suatu keharusan yang fundamental untuk membentuk sikap seorang siswa. Pada kegiatan membaca teks eksposisi, siswa dapat memperoleh pelajaran yang baru serta dapat memperluas khazanah ilmu pengetahuan. Oleh karena itu teks eksposisi menyajikan karangan yang berupa informasi yang bertujuan untuk memberi tahu, mengupas, menguraikan atau menerangkan sesuatu.

Pada karangan eksposisi yang disajikan untuk bahan pembelajaran untuk peserta didik berisi tentang pengetahuan yang diperoleh pada saat membaca di dalam sebuah teks, yang pada umumnya bertujuan untuk menjelaskan informasi tertentu agar dapat menambah ilmu pengetahuan bagi peserta didik, sehingga dengan membaca teks eksposisi maka peserta didik akan terbuka cakrawala pemikiran yang luas secara terperinci dari suatu hal

Berdasarkan tahap observasi awal yang dilakukan melalui proses wawancara yang dilakukan oleh peneliti di kelas X IPS 2 SMA Negeri 18 Makassar dapat dinyatakan bahwa pembelajaran bahasa Indonesia di sekolah tersebut dapat dikategorikan tingkat keberhasilan dalam hasil belajarnya, khususnya pada keterampilan membaca dapat dikategorikan masih belum efektif dan masih dibawah rata-rata. Salah satu faktornya yakni kurangnya efektivitas dalam keterampilan membaca tersebut dipicu oleh model pembelajaran yang digunakan oleh guru kurang variatif.

Hal ini menunjukkan bahwa dalam suatu pembelajaran bukan merupakan suatu hal yang mudah, karena keberhasilan pembelajaran ditentukan oleh proses pembuatan dan pelaksanaan keputusan. Pengambilan keputusan dan pemilihan metode serta pemilihan pendekatan materi serta keputusan untuk melaksanakan apa yang dipilih merupakan proses yang perlu dilakukan oleh pendidik. Faktor lain yang menyebabkan kurangnya efektivitas keberhasilan siswa yakni pemahaman guru dalam mengggunakan medel-model pengajaran yang kreatif.

Model yang diberikan guru untuk siswa dalam proses pembelajaran hanya bersifat satu arah. Mayoritas siswa di kelas hanya fokus pada buku teks yang cenderung membuat para siswa merasa jenuh dan kurang bersemangat dalam proses belajarnya. Kondisi yang demikian akan menyebabkan pembelajaran yang kurang efektif dalam tingkat keberhasilannya.

Berdasarkan masalah yang ditemukan seperti yang telah diuraikan sebelumnya, pembelajaran dengan model cooperative script dapat dijadikan salah satu alternatif yang tepat oleh guru sebagai metode pembelajaran yang berpusat pada keaktifan siswa dan mampu menumbuhkan minat dan motivasi siswa dalam membaca. Pembelajaran di sekolah diperlukan model-model pembelajaran yang baru serta efisien dan dapat menumbuhkan minat siswa dalam kegiatan membaca di sekolah. Dengan adanya pemilihan model yang tepat dan bervariasi dapat membuat siswa lebih mudah dalam memahami dan lebih dapat 
memacu diri meningkatkan motivasi dalam membaca. Kurangnya kebiasaan membaca dan motivasi dapat mempengaruhi penguasaan kosakata dan juga kemampuan mereka untuk memahami teks dengan baik.

\section{METODE}

Penelitian ini merupakan penelitian tindakan kelas (PTK). Penilitian PTK bertujuan untuk meningkatkan mutu atau pemecahan masalah pada sekelompok subyek yang diteliti dan mengamati tingkat keberhasilan atau akibat tindakannya, untuk kemudian diberikan tindakan lanjutan yang bersifat penyempurnaan tindakan atau penyesuaian dengan kondisi dan situasi sehingga diperoleh hasil yang lebih baik

Penelitian Tindakan Kelas adalah suatu kegiatan penelitian dengan mencermati sebuah kegiatan belajar yang diberikan tindakan, yang secara sengaja dimunculkan dalam sebuah kelas, yang bertujuan memecahkan masalah atau meningkatkan mutu pembelajaran di kelas tersebut. Tindakan yang secara sengaja dimunculkan. Penelitian tindakan kelas dilaksanakan dalam bentuk kegiatan bersiklus yang terdiri dari empat tahapan, yaitu: 1) perencanaan, 2) pelaksanaan, 3) pengamatan, dan 4) refleksi.

Sumber data dalam penelitian ini terdiri dari sumber primer dan sekunder. Sumber data primer diperoleh dari siswa kelas X IPS 2 SMA 18 Makassar yang berjumlah 35, dan guru (kolabolator) yang dijadikan objek penelitian. Sementara sumber sekunder data-data penunjang yang diperoleh dari data-data yang menunjang melalui wawancara dan sumber teoritis yang diperoleh dari informasi.

Data yang diperoleh dalam penelitian ini dianalisis secara deskriptif kualitatif. Analisisis data dilakukan pada tiap data yang dikumpulkan, dalam bentuk kuantitatif maupun data kualitatif. Data kualitatif dianalisis dengan menggunakan cara kuantitatif sederhana dengan persentase (\%) data kualitatif dianalisis dengan menggunakan penilaian-penilaian kualitatif (kategori).
Kriteria ketuntasan minimal dalam peningkatan kemampuan membaca siswa dengan menggunakan model cooperative script bahwa siswa yang memperoleh nilai sama dengan dan lebih besar dari 70 maka dapat dinyatakan tuntas belajar dalam proses belajar mengajar, serta siswa yang memperoleh nilai di bawah 70 maka siswa dinyatakan tidak tuntas dalam proses pembelajaran.

\section{HASIL DAN PEMBAHASAN}

Kelas yang digunakan dalam penelitian ini adalah kelas X IPS 2 yang terdiri atas 35 siswa. Kegiatan awal yang dilakukan peneliti yaitu mengadakan observasi awal untuk mengetahui keadaan sebenarnya serta mencari informasi untuk menemukan berbagai kendala yang dihadapi sekolah dalam proses pembelajaran bahasa Indonesia khususnya pada keterampilan membaca. Hal ini dikarenakan kemampuan siswa dalam pembelajaran keterampilan membaca masih belum mencapai KKM.

Pada tes pra siklus yang dilakukan di kelas X IPS 2 yang berjumlah 35 siswa, hanya 7 siswa yang nilainya mencapai $\mathrm{KKM}>70$. Mendapat fakta bahwa keterampilan membaca begitu rendah menunjukkan adanya hambatan yang dihadapi oleh siswa dalam pembelajaran bahasa Indonesia, khusunya pada aspek membaca maupun penggunaan model pembelajaran di dalam kelas. Pada tahap pra siklus siswa mengalami kesulitan dalam tingkat pemahaman inti dari teks bacaan eksposisi, siswa hanya sekadar membaca tanpa memerhatikan aspek yang perlu diperhatikan dalam keterampilan membaca.

Aspek-aspek yang dinilai sehingga dikategorikan mendapatkan nilai yang sangat baik dan sesuai meliputi pemahaman isi teks dari bacaan, pemahaman detail isi teks, keruntutan dalam pengungkapan teks dari bacaan, kelancaran pengungkapan, ketetapan pemilihan diksi serta ketetapan struktur kalimat. Berdasarkan hasil tes prasiklus menunjukkan keterampilan membaca masih rendah. 
Tabel 1. Hasil Penilaian Keterampilan Membaca Siswa Pra siklus

\begin{tabular}{cccc}
\hline No & Nama & Nilai & $\begin{array}{c}\text { Tingkat } \\
\text { Keberhasilan }\end{array}$ \\
\hline 1. & 001 & 65 & Sedang \\
2. & 002 & 55 & Rendah \\
3. & 003 & 78 & Tinggi \\
4. & 004 & 60 & Rendah \\
5. & 005 & 65 & Sedang \\
6. & 006 & 65 & Sedang \\
7. & 007 & 65 & Sedang \\
8. & 008 & 65 & Sedang \\
9. & 009 & 65 & Sedang \\
10. & 0010 & 55 & Rendah \\
11. & 0011 & 60 & Rendah \\
12. & 0012 & 60 & Rendah \\
13. & 0013 & 55 & Rendah \\
14. & 0014 & 78 & Tinggi \\
15. & 0015 & 55 & Rendah \\
16. & 0016 & 55 & Rendah \\
17. & 0017 & 55 & Rendah \\
18. & 0018 & 55 & Rendah \\
19. & 0019 & 55 & Rendah \\
20. & 0020 & 78 & Tinggi \\
21. & 0021 & 78 & Tinggi \\
22. & 0022 & 55 & Rendah \\
23. & 0023 & 60 & Rendah \\
24. & 0024 & 60 & Rendah \\
25. & 0025 & 55 & Rendah \\
26. & 0026 & 78 & Tinggi \\
27. & 0027 & 78 & Tinggi \\
28. & 0028 & 60 & Rendah \\
29. & 0029 & 60 & Rendah \\
30. & 0030 & 60 & Rendah \\
31. & 0031 & 60 & Rendah \\
32. & 0032 & 60 & Rendah \\
33. & 0033 & 55 & Rendah \\
34. & 0034 & 55 & Rendah \\
35. & 0035 & 60 & Rendah \\
\hline & Total & 2178 & \\
Rata-rata & 62 & \\
\hline & & & \\
\hline & & \\
\hline
\end{tabular}

Berdasarkan hasil yang telah diperoleh, bahwa tes yang dilakukam pada pra-siklus ini dari 35 siswa menunjukkan nilai rata-rata yang dicapai adalah 62. Dapat dikategorikan bahwa keterampilan membaca yang dilakukan sebelum tindakan ( pra-siklus) siswa X IPS 2 masih rendah.
Data kompetensi siswa pra-siklus ini dapat dilihat ketuntasan minimal (KKM).

Tabel 2. Penilaian Ketuntasan Siswa Pra-siklus

\begin{tabular}{clcc}
\hline No. & Kriteria & Frekwensi & Persentase \\
\hline 1. & Tuntas & 6 & 17 \\
2. & Tidak & 29 & 83 \\
& tuntas & & $100 \%$ \\
\hline & Jumlah & 35 &
\end{tabular}

Berdasarkan tabel di atas dapat diketahui bahwa masih banyak nilai siswa kelas $\mathrm{X}$ IPS 2 yang belum tuntas. Persentase siswa yang telah mencapai ketuntasan adalah 6 siswa atau $13 \%$, sedangkan yang belum mencapai ketuntasan terdiri dari 29 siswa atau $83 \%$. Adapun hasil nilai kemampuan membaca siswa kelas $\mathrm{X}$ IPS 2 SMA Negeri 18 Makassar yang masih rendah, maka peneliti berusaha untuk meningkatkan keterampilan membaca siswa kelas tersebut dengan menerapkan model pembelajaran coopertative script pada pelajaran bahasa Indonesia dengan materi membaca teks eksposisi.

Tabel 3. Hasil Penilaian Keterampilan Membaca Siswa Siklus I

\begin{tabular}{cccc}
\hline No & Nama & Nilai & $\begin{array}{c}\text { Tingkat } \\
\text { Keberhasilan }\end{array}$ \\
\hline 1. & 001 & 79 & Tinggi \\
2. & 002 & 60 & Rendah \\
3. & 003 & 79 & Tinggi \\
4. & 004 & 78 & Tinggi \\
5. & 005 & 78 & Tinggi \\
6. & 006 & 79 & Tinggi \\
7. & 007 & 78 & Tinggi \\
8. & 008 & 78 & Tinggi \\
9. & 009 & 78 & Tinggi \\
10. & 0010 & 60 & Rendah \\
11. & 0011 & 60 & Rendah \\
12. & 0012 & 78 & Tinggi \\
13. & 0013 & 60 & Rendah \\
14. & 0014 & 79 & Tinggi \\
15. & 0015 & 60 & Rendah \\
16. & 0016 & 60 & Rendah \\
17. & 0017 & 65 & Sedang \\
18. & 0018 & 60 & Rendah \\
\hline
\end{tabular}




\begin{tabular}{cccc} 
19. & 0019 & 60 & Rendah \\
20. & 0020 & 79 & Tinggi \\
21. & 0021 & 79 & Tinggi \\
22. & 0022 & 55 & Rendah \\
23. & 0023 & 78 & Tinggi \\
24. & 0024 & 78 & Tinggi \\
25. & 0025 & 55 & Rendah \\
26. & 0026 & 78 & Tinggi \\
27. & 0027 & 78 & Tinggi \\
28. & 0028 & 78 & Tinggi \\
29. & 0029 & 78 & Tinggi \\
30. & 0030 & 78 & Tinggi \\
31. & 0031 & 65 & Sedang \\
32. & 0032 & 79 & Tinggi \\
33. & 0033 & 60 & Rendah \\
34. & 0034 & 60 & Rendah \\
35. & 0035 & 79 & Tinggi \\
\hline \multicolumn{3}{c}{ Total } & 2486 \\
Rata-rata & 71 & \\
\hline
\end{tabular}

Berdasarkan pengamatan yang telah dilaksanakan pada siklus I belum menunjukkan hasil yang signifikan dari segi keaktifan siswa dan kuantitas nilai dalam penerapan model cooperative script keterampilan membaca teks eksposisi pada mata pelajaran bahasa Indonesia. Akan tetapi, pada siklus I ini menunjukkan bahwa beberapa siswa telah berhasil dalam memenuhi kriteria ketuntasan minimal (KKM). Adapun nilai rata-rata yang dicapai yakni 71, tercatat siswa yang memperoleh nilai < 70 (KKM) berjumlah 21 siswa atau $60 \%$ dan tercatat pula siswa yang memperoleh nilai > 70 (KKM) berjumlah 14 siswa atau $40 \%$.

Data kompetensi siswa pada siklus I dapat diuraikan nilai ketuntasan minimal (KKM) pada tabel 4 sebagai berikut.

Tabel 4. Penilaian Ketuntasan Siswa Siklus I

\begin{tabular}{clcc}
\hline No. & Kriteria & Frekwensi & Persentase \\
\hline 1. & Tuntas & 21 & 60 \\
2. & Tidak & 14 & 40 \\
& tuntas & & \\
\hline & Jumlah & 35 & $100 \%$ \\
\hline
\end{tabular}

Berdasarkan hasil pengamatan selama proses pembelajaran menunjukkan sikap antusias siswa dalam mengikuti pembelajaran bahasa Indonesia dengan menggunakan model cooperative script belum sepenuhnya berhasil. Meskipun sudah dijelaskan, tetapi masih terdapat beberapa siswa yang belum mampu meningkatkan tingkat pemahaman terhadap teks bacaan eksposisi yang telah dibagikan oleh guru sebagai fasilitator di dalam kelas.

Pada siklus I ini dikatakan berhasil apabila kemampuan membaca siswa telah mencapai $80 \%$ yang mendapatkan nilai $>70$ (KKM), dari data yang diperoleh terdapat 21 siswa atau $60 \%$ dari 35 siswa yang mendapatkan nilai >70 (KKM). Hal tersebut menunjukkan bahwa penerapan model cooperative script belum berhasil dalam meningkatkan kemampuan membaca khususnya pada teks eksposisi. Oleh karena itu perlunya dilaksanakan siklus ke II .

Tabel 5. Hasil Penilaian Keterampilan Membaca Siswa Siklus II

\begin{tabular}{cccc}
\hline No & Nama & Nilai & $\begin{array}{c}\text { Tingkat } \\
\text { Keberhasilan }\end{array}$ \\
\hline 1. & 001 & 85 & Tinggi \\
2. & 002 & 65 & Tinggi \\
3. & 003 & 85 & Tinggi \\
4. & 004 & 85 & Tinggi \\
5. & 005 & 85 & Tinggi \\
6. & 006 & 85 & Sedang \\
7. & 007 & 78 & Sangat \\
8. & 008 & 85 & Tinggi \\
9. & 009 & 85 & Tinggi \\
10. & 0010 & 85 & Tinggi \\
11. & 0011 & 65 & Tinggi \\
12. & 0012 & 90 & Tinggi \\
13. & 0013 & 85 & Tinggi \\
14. & 0014 & 85 & Tinggi \\
15. & 0015 & 78 & Sangat \\
16. & 0016 & 85 & Tinggi \\
17. & 0017 & 85 & Tinggi \\
18. & 0018 & 78 & Tinggi \\
19. & 0019 & 90 & Tinggi \\
20. & 0020 & 85 & Tinggi \\
21. & 0021 & 85 & Tinggi \\
22. & 0022 & 78 & Sedang \\
23. & 0023 & 85 & Tinggi \\
24. & 0024 & 78 & Tinggi \\
25. & 0025 & 65 & Tinggi \\
\hline & & &
\end{tabular}




\begin{tabular}{llll} 
26. & 0026 & 78 & Sangat \\
27. & 0027 & 78 & Tinggi \\
28. & 0028 & 85 & Tinggi \\
29. & 0029 & 90 & Tinggi \\
30. & 0030 & 85 & Sangat \\
31. & 0031 & 85 & Tinggi \\
32. & 0032 & 90 & Tinggi \\
33. & 0033 & 85 & Sedang \\
34. & 0034 & 65 & Sangat \\
35. & 0035 & 90 & Tinggi \\
\hline \multicolumn{5}{c}{ Total } & 2856 & \\
\hline \multicolumn{5}{c}{ Rata-rata } & 82 & \\
\hline
\end{tabular}

Nilai yang diperoleh siswa pada keterampilan membaca paad siklus II telah menunjukkan peningkatan yang maksimal dengan nilai rata-rata 82 , siswa yang memperoleh nilai $<70$ (KKM) 4 siswa atau $11 \%$ dan siswa yang memperoleh nilai > 70 (KKM) yaitu 31 siswa atau $89 \%$. Data kompetensi siswa siklus II dapat dijabarkan dari kriteria ketuntasan minimal (KKM).

Tabel 6. Penilaian Ketuntasan Siswa SiklusII

\begin{tabular}{llcc}
\hline No. & Kriteria & Frekwensi & Persentase \\
\hline 1. & Tuntas & 31 & 89 \\
1. & $\begin{array}{l}\text { Tidak } \\
\text { tuntas }\end{array}$ & 4 & 11 \\
\hline & Jumlah & 35 & $100 \%$ \\
\hline
\end{tabular}

Berdasarkan tabel penilaian ketuntasan siswa pada keterampilan membaca teks eksposisi di atas, dapat membuktikan adanya peningkatan yang signifikan, karena nilai sebelum tindakan hanya $17 \%$ siswa yang mendapatkan KKM. Setelah masuk pada siklus I telah terdapat $60 \%$ siswa yang mencapai KKM sedangkan pada siklus II sebanyak $83 \%$, hal ini telah memenuhi indikator keberhasilan yaitu $80 \%$ siswa memenuhi KKM dari sekolah yaitu 70. Hal ini menunjukkan bahwa penerapan model cooperative script telah dikategorikan berhasil. Oleh karena itu berdasarkan pengamatan dan analisa hasil ketarampilan membaca siswa, guru dan peneliti mengakhiri siklus tindakan penelitian kelas dalam pembelajaran keterampilan membaca dengan menggunakan model cooperative script ini.

Berdasarkan hasil penelitian yang telah dipaparkan, penerapan model cooperative script dapat meningkatkan keterampilan membaca siswa kelas X IPS 2 SMA Negeri 18 Makassar. Pada model pembelajaran cooperative script ini siswa dapat lebih aktif dan kreatif dalam proses pembelajaran, khususnya pada saat menemukan dan mencari inti sari dalam teks eksposisi. Terutama pada saat pelaksanaan diskusi berlangsung, siswa dengan antusias membacakan hasil dari kelompok mereka dan memaparkannya dengan lugas dan penuh semangat di depan kelas.

Model pembelajaran cooperative script ini diadaptasikan dengan kemampuan siswa dalam proses pembelajarannya serta membangun kemampuan siswa untuk membaca dan menyusun rangkuman berdasarkan materi yang dibacanya, sehingga dapat meningkatkan pemahaman konsep siswa terhadap materi yang diajarkan (Natalina, Nursal, \& Srini, 2013).

Dengan model pembelajaran Cooperative Script, siswa akan terlatih mengembangkan ide-idenya sehingga siswa dapat mengkonstruksi sendiri pengetahuan (Suryani, Atmaja, \& Natajaya, 2013). Dengan begitu siswa tidak hanya terpaku kepada apa yang disampaikan oleh guru saja, tetapi bisa mengembangkan pengetahuan yang dia terima dari sumber lain. Langkah yang harus dilakukan dalam model pembelajaran Cooperative Script (Miftahul, 2014).

Penelitian tindakan kelas ini dilakukan dalam dua siklus. Pada proses perencanaan siklus I dan II, proses pembelajaran dilakukan di dalam kelas dengan menggunakan model pembelajaran cooperative script, hal ini menunjukan bahwa perencanaan pembelajaran disusun dan dirancang secara rinci dan terstruktur.

Setiap perencanaan pembelajaran membahas hal-hal yang akan dilakukan dalam bentuk RPP. Perencanaan pembelajaran yang mencakup hal-hal yang 
dikerjakan secara sistematis dengan kebutuhan dan tujuan pembelajaran dalam membaca teks eksposisi. Pada tahap pelaksanaan tindakan, peneliti bersama guru mulai menerapkan model pembelajaran cooperative script dalam proses pembelajaran, serta mengamati kegiatan di dalam kelas dari awal hingga akhir pertemuan.

Tahap observasi yang dilakukan peneliti, merupakan tahap setelah diterapkannya model pembelajaran cooperative script. Sistem pengamatan difokuskan pada hasil dari lembar observasi dan hasil tes evaluasi siswa pada setiap akhir siklus. Hasil dari observasi tersebut dianalisis sesuai dengan ketentuan dalam proses tindakan kelas dan menindak lanjuti hasil tersebut dengan melakukan refleksi. Refleksi dilakukan untuk mengetahui adanya peningkatan dari keterampilan membaca siswa pada mata pelajaran bahasa Indonesia. Hasil dari refleksi tersebut dijadikan suatu acuan dalam pelaksanaan tindakan siklus selanjutnya.

Berdasarkan hasil pengamatan peneliti, baik pada proses kegiatan maupun pada hasil akhir yaitu peningkatan keterampilan membaca pada siklus II berhasil sesuai tujuan kegiatan penelitian. Penggunaan model pembelajaran cooperative script efektif digunakan dalam upaya meningkatkan keterampilan membaca pada teks eksposisi sehingga penelitian ini tidak perlu dilanjutkan pada siklus berikutnya.

\section{KESIMPULAN}

Berdasarkan hasil pengamatan peneliti, baik pada proses kegiatan maupun pada hasil akhir yaitu peningkatan keterampilan membaca pada siklus II berhasil sesuai tujuan kegiatan penelitian. Penggunaan model pembelajaran cooperative script efektif digunakan dalam upaya meningkatkan keterampilan membaca pada teks eksposisi, khususnya pada saat menemukan dan mencari inti sari dalam teks eksposisi. Terutama pada saat pelaksanaan diskusi berlangsung, siswa dengan antusias membacakan hasil dari kelompok mereka dan memaparkannya dengan lugas dan penuh semangat di depan kelas.

Peningkatan keterampilan membaca siswa tersebut terbukti dengan perolehan nilai rata-rata siswa di setiap siklusnya. Pada siklus I 60\% sedangkan siklus II mencapai $89 \%$. Hal ini menunjukkan adanya peningkatan keterampilan membaca siswa dari siklus I ke siklus II.

\section{DAFTAR PUSTAKA}

Arikunto, Suharsimi. 2011. Penelitian Tindakan Kelas.Jakarta: Bumi Aksara.

Mansyur, U. 2018. Kiat dan Teknik Penulisan Skripsi bagi Mahasiswa. INA-Rxiv. https://doi.org/10.31227/osf.io/juds7

Mansyur, U. 2018. Korelasi Minat Baca dengan Kemampuan Menulis Karya Tulis Ilmiah Mahasiswa Pendidikan Bahasa Indonesia UMI. Multilingual: Jurnal Kebahasaan dan Kesastraan, 17(1), 11-22.

Mansyur, U. \& Rahmat. 2019. Pelatihan Penelitian Tindakan Kelas bagi Guru MTs Mizanul 'Ulum Desa Sanrobone Kabupaten Takalar. J-ABDIPAMAS: Jurnal Pengabdian kepada Masyarakat, 3(2), 47-54.

Manurung Novita Sari. 2016. Pengaruh Model Pembelajaran Cooperative Script Terhadap Kemampuan Memahami Teks Berita (eksposisi).

Meilani Rima dkk. 2016. Penerapan Model Pembelajaran Cooperative Script untuk Meningkatkan Hasil Belajar. Jurnal Pendidikan Manajemen Perkantoran, Volume 1 Nomor 1 Hal: 186-197.

Miftahul. 2014. Model-model Pengajaran dan Pembelajaran: Isu-isu Metodis dan Paradigmatisi. Yogyakarta: Pustaka Pelajar.

Natalina, M.. dkk. 2013. Penerapan Model Pembelajaran Cooperative Script Untuk Meningkatkan Aktivitas dan Hasil Belajar Biologi Siswa Kelas VII SMP Negeri 14 Pekanbaru. Jurnal 
Biogenesis, 44-51.

Nurgiantoro, Burhan. 2012. Penilaian Dalam Pembelajaran Bahasa Berbasis Kompetensi. Yogyakarta.

Nurgiantoro, Burhan. 2016. Penialian Pembelajaran Bahasa Berbasis Kompetensi Edisi Kedua. Yogyakarta.

Nurhadi, 2016. Teknik Membaca. Jakarta: Bumi Aksara.

Paizaluddin, dkk 2016. Penelitian Tindakan Kelas (Class Room Action Research) Panduan Teoritis dan Praktis. Bandung: Alfabeta.

Rusman. 2010. Model-Model Pembelajaran Mengembangkan Profesioanalisme Guru. Jakarta: Rajawali Pers.

Rusman. 2014. Seri Maodel-model Pembelajaran Mengembangkan Profesional Guru Edisi Kedua. Jakarta: Rajawali Pers.
Suryani, dkk. 2013. Pengaruh Model Pembelajaran Cooperative Script terhadap Hasil Belajar Sosiologi Ditinjau dari Motivasi Berprestasi Siswa. e-Journal Program Pascasarjana Universitas Pendidikan Ganesha.

Tampubolon, 2015. Kemampuan Membaca,Teknik Membaca Efektif dan Efisien. Bandung: Angkasa.

Tarigan Henry Guntur, 2008. Membaca sebagai Suatu Keterampilan Berbahasa. Bandung: Angkasa.

Umiaty, M., \& Mansyur, U. 2017. Learning Community dalam Pembelajaran Keterampilan Berbicara Bahasa Inggris Siswa Kelas XII SMA LPP UMI Makassar. Retorika: Jurnal Bahasa, Sastra, dan Pengajarannya, 10(1), 13-19. 